\title{
Natal dispersal and recruitment of two Bonelli's Eagles Aquila fasciata: a four-year satellite tracking study
}

\author{
Luis CADAhíA ${ }^{1,2^{*}}$, Pascual López-López ${ }^{2,3}$, Vicente Urios ${ }^{2}$, Álvaro Soutullo ${ }^{2}$ \& Juan J. \\ $\mathrm{NEGRO}^{4}$
}

\begin{abstract}
${ }^{1}$ Center for Ecological and Evolutionary Synthesis, Department of Biology, University of Oslo, P.O. Box 1066, Blindern, N-0316 Oslo, NORWAY, e-mail: luis.cadahia@gmail.com; luis.cadahia@bio.uio.no

${ }^{2}$ Estación Biológica Terra Natura (Terra Natura Foundation - CIBIO), University of Alicante, Post Box 99, E-03080, Alicante, SPAIN

${ }^{3}$ Cavanilles Institute of Biodiversity and Evolutionary Biology, University of Valencia, Polígono de la Coma s/n, 46980 Paterna, Valencia, SPAIN

${ }^{4}$ Evolutionary Ecology Department, Estación Biológica de Doñana, CSIC, Avda, Américo Vespucio, s/n, 41092, Seville,
\end{abstract} SPAIN

Cadahía L., López-López P., Urios V., Soutullo Á., Negro J. J. 2009. Natal dispersal and recruitment of two Bonelli's Eagles Aquila fasciata: a four-year satellite tracking study. Acta Ornithol. 44: 193-198. DOI 10.3161/000164509X482777

\begin{abstract}
To study natal dispersal and recruitment to the breeding population in Bonelli's Eagle, two nestlings were tagged with satellite transmitters in the Iberian Peninsula in 2002. Their monthly ranges and distances were computed and fitted to regression models to describe their general trend. One bird, a female, dispersed and settled rapidly in an area which she explored intensively during four years and which finally became her first breeding site. The natal dispersal distance was $441 \mathrm{~km}$, and the bird cannot therefore be considered philopatric. The other bird, a male, alternated between long travelling episodes and settlement in particular areas, exploring different regions both distant from and close to his natal territory, but no breeding attempt could be confirmed after four years of tracking. The large distances we recorded confirm the potential for gene flow among populations but, in comparison with our results from previous studies, they suggest that Bonelli's Eagles may show high variation in their natal dispersal distances and use different dispersal strategies.
\end{abstract}

Key words: Aquila fasciata, Bonelli's Eagle, Argos satellite telemetry, natal dispersal, philopatry, PTT, recruitment, time series analysis

Received — Jan. 2009, accepted — Sept. 2009

Natal dispersal, i.e., the movements performed between the departure from the parental territory and the settlement in the first breeding site (Greenwood \& Harvey 1982), is an essential demographic process which influences ecological dynamics, spatial distribution, and genetic structure of populations (Johnson \& Gaines 1990, Clobert et al. 2001, Bullock et al. 2002). To study natal dispersal in many bird species, remote-tracking systems have been frequently used, especially VHF radio-tracking techniques. However, continuous tracking of animal movements is difficult and logistically complex to carry out, especially in those cases in which long distance movements, large ranges and delayed reproduction are present (Kenward 2001). For these cases, satellite tracking techniques, though expensive, can be very helpful. Bonelli's Eagle Aquila fasciata juveniles usually leave their parental territories suddenly and perform large movements during dispersal (Cheylan et al. 1996, Real \& Mañosa 2001, Cadahía et al. 2005, 2007b) and, hence, the report of the distribution of the natal dispersal distances could be short-distance biased using conventional radio-tracking methods.

Bonelli's Eagle is an 'endangered' raptor in Europe (BirdLife 2004). The strongholds of the European breeding population occur in the Iberian Peninsula, where the species is also considered 'endangered' both in Spain and Portugal (Martí \& Del Moral 2003, Real 2004). Previous studies have described juvenile Bonelli's Eagle 
movement patterns, the maximum distance juveniles can reach, the extent of their hourly and daily movements or the habitat they select during the initial phases of dispersal (Cheylan et al. 1996, Real \& Mañosa 2001, Balbontín 2005, Balbontín \& Ferrer 2005, Cadahía et al. 2005, 2007b). Here we provide a comprehensive account of the movements performed by two long-term tracked Bonelli's Eagle juveniles throughout the natal dispersal period and describe the recruitment to the breeding population registered for one of them, after four years of satellite tracking.

Two nestling Bonelli's Eagles, a male and a female, were tagged with solar-powered PTT-100s (Microwave Telemetry Inc. USA, 35g, 17.4 x 29.1 x $62.5 \mathrm{~mm}$, antenna $17.8 \mathrm{~cm}$ ) in eastern Spain (provinces of Valencia and Castellón), on 26 April and 9 May 2002, respectively. Both nestlings were removed from their cliff-located nests (distant 91 $\mathrm{km}$ ) when they were ca. 50 days old, weighed, measured and fitted with the PTTs. These were fixed as back-packs to the birds' body by a breakaway, non-elastic, Teflon harness and were in both cases under $3 \%$ of the birds' body mass (Kenward 2001). Gender of nestlings was established by molecular methods (Griffiths et al. 1998, Fridolfsson \& Ellegren 1999) using a blood sample (around $0.5 \mathrm{ml}$ ) collected from the brachial vein and stored in ethanol $70 \%$. During the nesting period, nestlings' age was estimated according to feather growth and pattern (Torres et al. 1981, GilSánchez 2000) using a spotting scope from a distant point. After tagging and measuring, exact age was computed as: age $=0.200 \times$ tail length (central rectrix) $(\mathrm{mm})+16.262$ (Mañosa et al. 1995).

Both PTTs were set to an 8-h on / 120-h off schedule. Estimation and initial management of the locations was made by Argos, a satellite-based location and data collection system (Argos 1996, Kenward 2001). Argos location classes (LC) 3, 2 and 1, with nominal accuracy < $150 \mathrm{~m}, 150-350 \mathrm{~m}$ and 350-1000 m, respectively, were used (Argos 1996, but see Keating et al. 1991, Soutullo et al. 2007). Lower quality locations (LC 0, A and B) were also employed, after filtering them according to Argos accuracy tests (see Soutullo et al. 2007) and the maximum speed per hour and per day calculated from Bonelli's Eagle juveniles tagged with GPS (see Cadahía et al. 2007b).

To describe the movements of both birds during natal dispersal we computed distance and range size variables. Since we were interested in modelling how the distancing and settlement patterns develop, we only used data after departure from the parental territories (see Cadahía et al. 2008). For a general description we calculated the annual ranges size, the median and maximum annual distance to natal nests, and, in the case of the recruitment we registered (the female), also the natal dispersal distance, i.e., the length of a straight line connecting the natal nest with the first breeding site (Greenwood \& Harvey 1982). For annual computations, years were defined in relation to birds' birth. For a more detailed description, we computed monthly distances to natal nests (ND) as the median of all distances calculated within each Gregorian month, and monthly range sizes (RS), using a 95\% Minimum Convex Polygon of all the locations within a given month. In the recruitment case, we also computed the monthly distance to the first breeding site (BD). The spatial analyses were performed with ArcMap 9.2 (ESRI, Inc.).

To test whether autocorrelation existed in the monthly variables, we constructed autocorrelograms. All the distance data presented significant autocorrelation, and, to remove it, we used "autoregressive integrated moving-average" models (ARIMA models; Box \& Jenkins 1976, Urios et al. 2007). Autocorrelation was eliminated using a first-order moving average process (an ARIMA (0, $0,1)$ model) for the female's ND and BD, and using a first-order autoregressive process (an ARIMA $(1,0,0)$ model) for the male's ND. Then, we fitted the (filtered) distance and range size variables to appropriate mathematical models to describe their general trend. Time series analyses were carried out with $\mathrm{R}$ 2.7.0 ( $\mathrm{R}$ Development Core Team 2008). All other analyses were performed with SPSS 15.0 (SPSS, Inc.).

During the approximately four years of both birds' tracking (until both PTTs ceased working), we collected 461 useful Argos satellite fixes for the female and 390 for the male, respectively. In general, the female reached more distant locations to its natal area than the male did, but, in the second and fourth year, covered smaller annual areas (Table 1, Fig. 1). The female's monthly distance to the natal nest (ND) rapidly increased during the first months of life, but then became rather constant (Table 2, Fig. 2a). Similarly, both the monthly distance to the first breeding site (BD) and the monthly area (RS) covered by the bird decreased rapidly and, from the third month after dispersing on, remained relatively steady (Table 2, Fig. 2a). 
Table 1. Median and maximum annual distances $(\mathrm{km})$ and annual range size $\left(\mathrm{km}^{2}\right)$ covered by two Bonelli's Eagle juveniles during their natal dispersal period (in this case, first four years of life) in Spain.

\begin{tabular}{lcccccccc}
\hline & \multicolumn{4}{c}{ Female } & \multicolumn{4}{c}{ Male } \\
& $1^{\text {st }}$ year & $2^{\text {nd }}$ year & $3^{\text {rd }}$ year & $4^{\text {th }}$ year & $1^{\text {st }}$ year & $2^{\text {nd }}$ year & $3^{\text {rd }}$ year & $4^{\text {th }}$ year \\
\hline Median annual distance & 413 & 448 & 434 & 441 & 236 & 201 & 97 & 117 \\
Maximum annual distance & 503 & 533 & 498 & 541 & 332 & 285 & 199 & 286 \\
Annual range size & 66609 & 5730 & 3874 & 2468 & 16397 & 10308 & 2907 & 21244 \\
\hline
\end{tabular}

This means that, soon after dispersing, the female settled in an area that, after being intensively explored during most of the whole dispersal period (1000 $\mathrm{km}^{2}$ per month as an average), finally became its first breeding site (Fig. 1). In fact, considering an average Bonelli's Eagle territory radius between $4.9 \mathrm{~km}$ (Sanz et al. 2005) and 11.9 $\mathrm{km}$ (Arroyo et al. 1995) in Spain, the female visited locations within its first breeding territory as soon as May 2005, i.e., already during the previous breeding season, and stayed within an average monthly distance of $13 \mathrm{~km}$ from its final nest location during the remaining time. In the male, the monthly distance to the natal nest (ND) indicated that the bird was already far away shortly after dispersing, but, after one year and a half, it moved to an area closer to its parental territory, just to move away once more after another one and a half years (Table 2, Fig. 2b). Despite these large movements, which made its annual range to be greater than that of the female on the second and fourth year (Fig. 1), the monthly range size (RS) decreased during the initial months after dispersing and became rather stable afterwards (Table 2, Fig. 2b). According to this, except for the large travelling episodes, the bird explored monthly a)

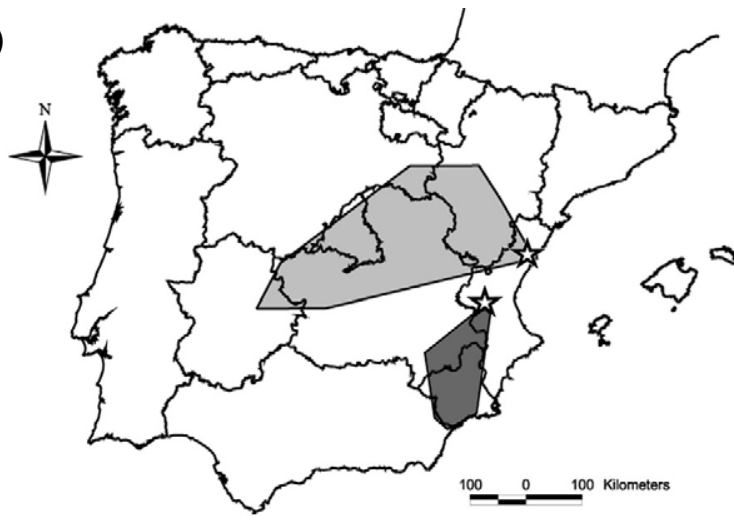

c)

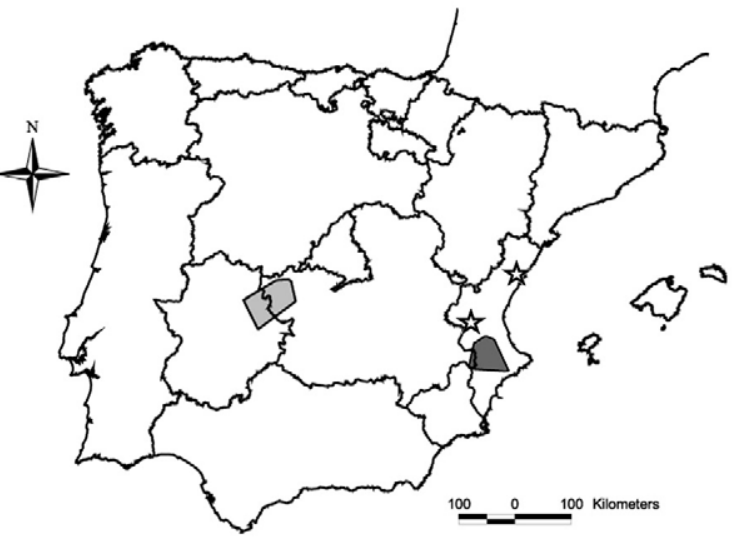

b)

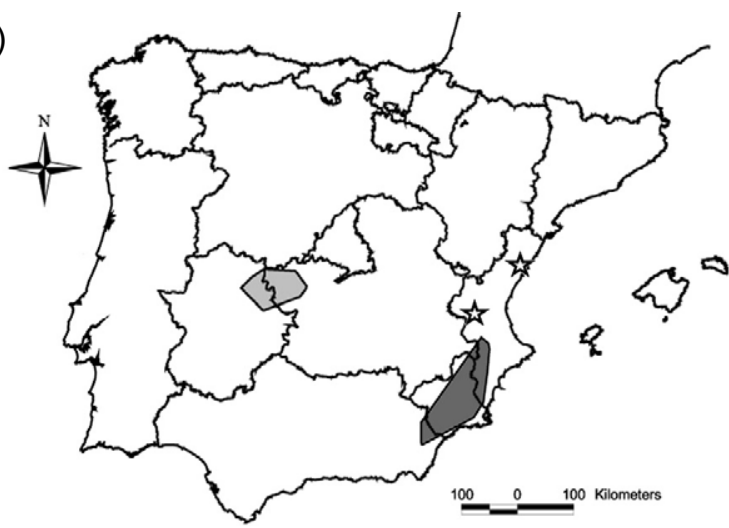

d)

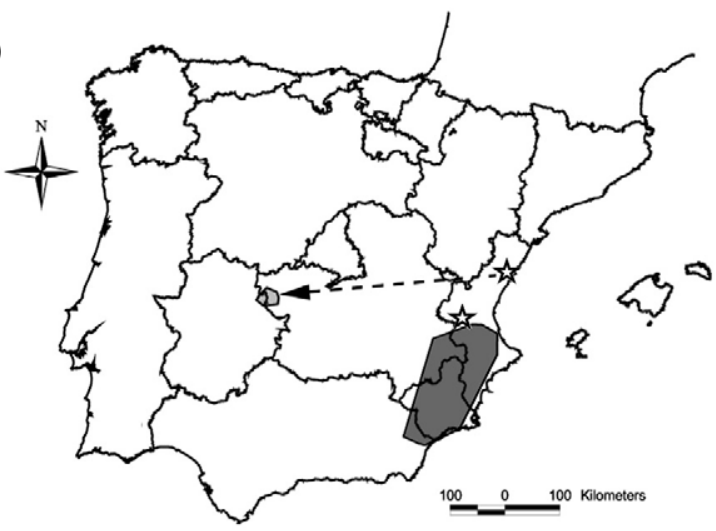

Fig. 1. Annual home ranges of two juvenile Bonelli's Eagles during natal dispersal in Spain, computed using the 95\% Minimum Convex Polygon. Autonomous Communities (Spanish administrative units) are shown. a) to d) indicate first to fourth year of life. Light grey: female; dark grey: male. Stars designate natal nests. The broken arrow represents the female's natal dispersal distance, i.e., the distance from the natal nest to the first breeding place. 
Table 2. Regression models used to describe the movement patterns of two juvenile Bonelli's Eagles during natal dispersal in Spain. ND: monthly distance to natal nest $(\mathrm{km})$; RS: monthly range size $\left(\mathrm{km}^{2}\right)$; BD: monthly distance to first breeding site $(\mathrm{km})$; 'time' indicates months. The regressions of the distance variables are computed on the residuals of ARIMA models used to remove autocorrelation from the original data. ${ }^{\text {a }}$ - In the male's ND the regression model was calculated using the original data, despite the existing autocorrelation, to illustrate the general tendency of the bird's movement, since the residuals of the ARIMA model did not show any straightforwardly informative pattern.

\begin{tabular}{lrrr}
\hline \multicolumn{1}{c}{ Regression model } & df & F & p \\
\hline Female & & & \\
ND $=14.54-139.16 /$ time & 1,43 & 49.359 & 0.001 \\
RS $=709+8088 /$ time & 1,40 & 19.324 & 0.001 \\
BD $=-17.35+163.51 /$ time & 1,43 & 58.020 & 0.534 \\
Male & & & 0.326 \\
ND $=230.67+5.70 \times$ time $-0.84 \times$ time $^{2}+0.02 \times$ time $^{3}$ & 3,42 & 26.643 & 0.001 \\
RS $=446+9981 /$ time & 1,39 & 9.316 & 0.656 \\
\hline
\end{tabular}

areas of approximately similar size $\left(800 \mathrm{~km}^{2}\right.$ as an average) during most of its dispersal period.

At the beginning of the breeding season in 2006, the female's movements were confined to a restricted area in central Spain. After three field trips, we confirmed that the bird was attending an
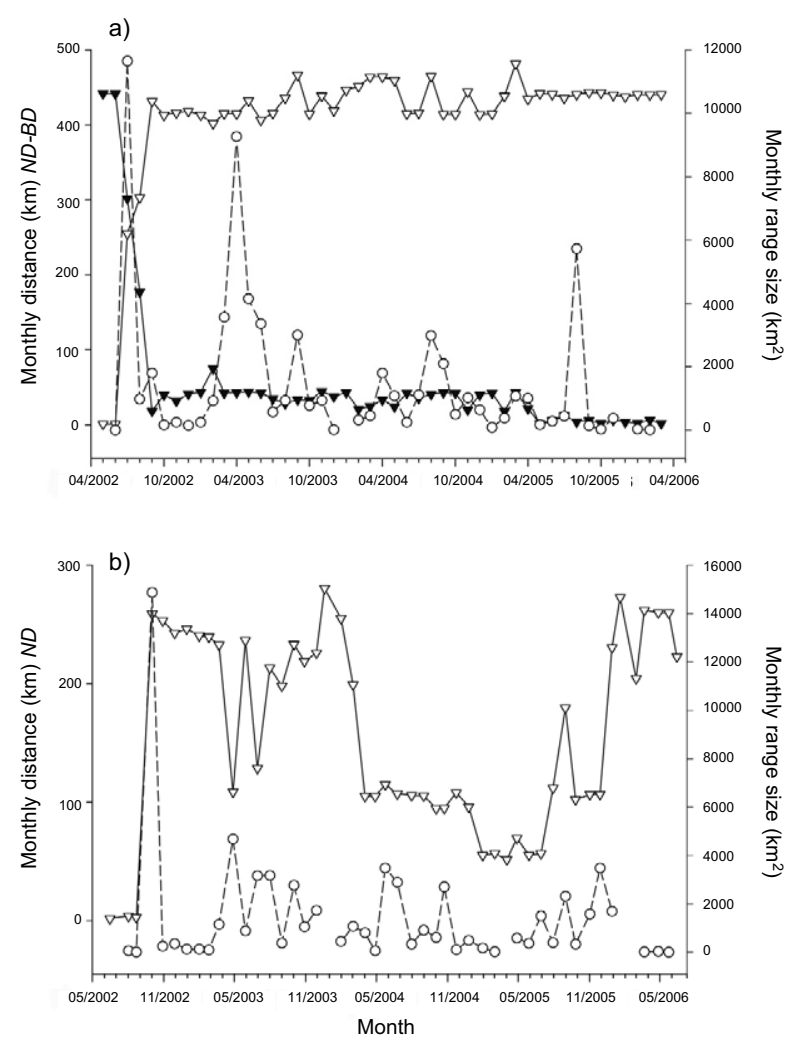

Fig. 2. Changes in time of monthly distances and home range sizes of two juvenile Bonelli's Eagles during natal dispersal in Spain. a: female; b: male. Open circles: monthly range size (RS); empty triangles: monthly distance to natal nest (ND); filled triangles (only female): monthly distance to first breeding site (BD). active nest located $441 \mathrm{~km}$ from its natal nest (i.e., natal dispersal distance; Fig. 1d) and that both it and its unbanded mate retained juvenile plumage features. Egg laying took place in the first fortnight of April 2006 but the breeding failure was confirmed on 6 June. During the following breeding season the pair was observed successfully raising a chick that probably hatched in the second fortnight of April 2007. As to the male we also tracked for four years, we could not confirm any breeding attempt before losing contact, but its last locations were assembled in a breeding area around $260 \mathrm{~km}$ south from its natal territory.

It is well known that Bonelli's Eagle juveniles can perform large movements during natal dispersal (Cheylan et al. 1996, Real \& Mañosa 2001, Cadahía et al. 2005, 2007b), a phase which may last several years until birds reach sexual maturity. Hitherto, recruitments of Bonelli's Eagles reported natal dispersal distances ranging from $50 \mathrm{~km}$ to $320 \mathrm{~km}$ in southeastern France (Cheylan et al. 1996) and from $5 \mathrm{~km}$ to $120 \mathrm{~km}$ in southern Spain (Balbontín \& Ferrer 2009). In comparison, our female was recruited in a more distant location (441 km, Fig. 1d), which implies that it cannot be considered philopatric, i.e., it did not return to its natal area or nearby to attempt breeding. In addition, if the male we monitored for four years were actually breeding, it should also be considered non-philopatric, but, as we could not find the bird, this statement must be taken with caution. In any case, all these individual differences make it difficult to clarify the real distribution of the natal dispersal distances in the western European population of Bonelli's Eagle. Several factors, like geographical 
origin, population density, foraging opportunities, etc., are likely to influence the natal dispersal distance in each particular case and account for the observed variation.

The different evolution of range size and movement patterns in the two studied birds might reflect different dispersal strategies regarding how and when individuals decide to settle in a potential first-breeding site. During almost the entire natal dispersal period the female moved around an area within which it finally attempted breeding (Fig. 1, Fig. 2a). This juvenile took advantage of previously built nests in the area, forming a new pair in a marginal area by recolonising an old territory (J. Cisneros, P. González, pers. comm.). In contrast, the male alternated long-distance travelling episodes with settlement in particular areas during the four years. This enabled him to explore areas spread along the south-east region of the Iberian Peninsula, both distant and close to his natal territory (Fig. 1, Fig. 2b). With this strategy the juvenile might be checking different breeding territories, monitoring the availability of breeding opportunities, as it has been suggested for other eagle species, like Spanish Imperial Eagle Aquila adalberti (Ferrer 1993, 2001) or Golden Eagle A. chrysaetos (Urios et al. 2007). In fact, this dissimilar behaviour has already been suggested as a sex-related difference in the dispersal strategy of Bonelli's Eagle (Balbontín \& Ferrer 2009).

This complicated scenario of dispersing strategies and natal dispersal distances is also noticeable when looking at genetic data. Cadahía et al. (2007a) studied mitochondrial DNA sequences in Bonelli's Eagles from the Iberian Peninsula and Morocco and found no evidence of significant genetic structure. To account for this result, the authors proposed the occurrence of gene flow among different areas of the distribution range through long natal dispersal events. However, when using microsatellites as molecular markers, the results obtained revealed the existence of significant genetic structure in some Bonelli's Eagle populations within the Iberian Peninsula (Mira 2006). In this case, the philopatric behaviour of the species was put forward as the most likely explanation. These apparently contradictory results, along with the diverse natal dispersal distances reported, point out the need to collect more data, both genetic and ecological, to disentangle how this process really occurs, including its implications for the demography and conservation of the western European population of the species.
ACKNOWLEDGEMENTS We are grateful to the Conselleria de Territori i Habitatge of the Generalitat Valenciana (J. Jiménez, P. Mateache, A. Izquierdo and A. García i Sanz, along with the forest rangers) and the Spanish Ministry of Environment (V. García Matarranz, P. García Domínguez) for permission to get access to the nests, partial funding and support during fieldwork. Thanks are also due to P. González Mencía and S. Villaverde for help in trapping the female in 2006, and to J. Cisneros and J. M. Blanco for providing information in 2007. This project was funded by Terra Natura Foundation. We are grateful to M. Gallardo, R. Limiñana, A. Menargues, C. García, D. Pavón and M. Catalán for their valuable help and support in the field trips as well as for their comments on the manuscript, and to $L$. van Oudenhove for her mathematical support. L.C. and P.L.-L. were supported by FPU grants of the Spanish Ministry of Education (references AP2001-1444 and AP2005-0874, respectively).

\section{REFERENCES}

Argos 1996. User's Manual. CLS/Service Argos. Toulouse. Arroyo B., Ferreiro E., Garza V. 1995. [Bonelli's eagle (Hieraaetus fasciatus) in Spain. Census, reproduction and conservation]. Technical report. Technical collection ICONA, Madrid.

Balbontín J. 2005. Identifying suitable habitat for dispersal in Bonelli's Eagle: An important issue in halting its decline in Europe. Biol. Cons. 126: 74-83.

Balbontín J., Ferrer M. 2005. Condition of large brood in Bonelli's Eagle Hieraaetus fasciatus. Bird Study 52: 3741.

Balbontín J., Ferrer M. 2009. Movements of juvenile Bonelli's Eagles Aquila fasciata during dispersal. Bird Study 56: 8695.

BirdLife International 2004. Birds in Europe: population estimates, trends and conservation status. BirdLife International. Cambridge.

Box G. E. P., Jenkins J. M. 1976. Time series analysis: Forecasting and control. 2nd ed. Holden-Day. San Francisco.

Bullock J. M., Kenward R. E., Hails R. S. (eds). 2002. Dispersal Ecology. Blackwell. Oxford.

Cadahía L., López-López P., Urios V., Negro J. J. 2008. Estimating the onset of dispersal in endangered Bonelli's Eagle Hieraaetus fasciatus tracked by satellite telemetry: a comparison between methods. Ibis 150: 416-420.

Cadahía L., Negro J. J., Urios V. 2007a. Low mitochondrial DNA diversity in the endangered Bonelli's Eagle (Hieraaetus fasciatus) from SW Europe (Iberia) and NW Africa. J. Ornithol. 148: 99-104.

Cadahía L., Urios V., Negro J. J. 2005. Survival and movements of satellite-tracked Bonelli's Eagles Hieraaetus fasciatus during their first winter. Ibis 147: 415-419.

Cadahía L., Urios V., Negro J. J. 2007b. Bonelli's Eagle Hieraaetus fasciatus juvenile dispersal: hourly and daily movements tracked by GPS. Bird Study 54: 271-274.

Cheylan G., Ravayrol A., Cugnasse J.-M., Billet J.-M., Joulot C. 1996. [Dispersal of Bonelli's Eagles Hieraaetus fasciatus juveniles ringed in France]. Alauda 64: 413-419. 
Clobert J., Danchin E., Dhont A. A., Nichols J. (eds). 2001. Dispersal - causes, consequences and mechanisms of dispersal at the individual, population and community level. Oxford University Press. Oxford.

Ferrer M. 1993. Juvenile dispersal behaviour and natal philopatry of a long-lived raptor, the Spanish imperial eagle Aquila adalberti. Ibis 135: 132-138.

Ferrer M. 2001. The Spanish imperial eagle. Lynx Editions. Barcelona.

Fridolfsson A.-K., Ellegren H. 1999. A simple and universa method for molecular sexing of non-ratite birds. J. Avian Biol. 30: 116-121.

Gil-Sánchez J. M. 2000. [Effect of altitude and prey availability in laying date in Bonelli's Eagle (Hieraaetus fasciatus) in the province of Granada (SE Spain)]. Ardeola 47: 1-8.

Greenwood P. J., Harvey P. H. 1982. The natal and breeding dispersal of birds. Ann. Rev. Ecol. Syst. 13: 1-21.

Griffiths R., Double M. C., Orr K., Dawson R. J. G. 1998. A DNA test to sex most birds. Mol. Ecol. 7: 1071-1075.

Johnson M. L., Gaines M. S. 1990. Evolution of dispersal: theoretical models and empirical tests using birds and mammals. Ann. Rev. Ecol. Syst. 21: 449-480.

Keating K. A., Brewster W. G., Key C. H. 1991. Satellite telemetry: performance of animal-tracking systems. J. Wildlife Manage. 55: 160-171.

Kenward R. 2001. A manual for wildlife radio tagging Academic Press. London, San Diego.

Mañosa S., Real J., Codina J. 1995. Age estimation and growth patterns in nestling Bonelli's Eagles. J. Raptor Res. 29: 273-275.

Martí R., Del Moral J. C. (eds). 2003. [Atlas of the breeding birds of Spain]. Dirección General de Conservación de la Naturaleza - Sociedad Española de Ornitología (SEO). Madrid.

Mira S. 2006. Population genetics of an endangered species: the Bonelli's eagle (Hieraaetus fasciatus). PhD Thesis, University of Algarve, Portugal.

R Development Core Team 2008. R: A language and environment for statistical computing. R Foundation for Statistical Computing, Vienna, Austria. ISBN 3-900051-07-0, URL http://www.R-project.org.

Real J. 2004. [Bonelli's Eagle, Hieraaetus fasciatus]. In: Madroño A., González C., Atienza J. C. (eds). [Redbook of the birds of Spain]. Dirección General para la Conservación de la Biodiversidad - SEO/BirdLife, Madrid, pp: 154-157.

Real J., Mañosa S. 2001. Dispersal of juvenile and immature Bonelli's Eagles in Northeastern Spain. J. Raptor Res. 35: 9-14.

Sanz A., Mínguez E., Anadón J. D., Hernández V. 2005. [Heterogeneous use of space in three breeding territories of Bonelli's Eagle (Hieraaetus fasciatus)]. Ardeola 52: 347-350.
Soutullo A., Cadahía L., Urios V., Ferrer M., Negro J. J. 2007. Accuracy of lightweight satellite telemetry: a case study in the Iberian Peninsula. J. Wildlife Manage. 71: 1010-1015.

Torres J. A., Jordano P., León A. 1981. [Diurnal birds of prey of the province of Cordoba]. Publicaciones del Monte de Piedad y Caja de Ahorros de Córdoba. Madrid.

Urios V., Soutullo A., López-López P., Cadahía L., Limiñana R., Ferrer M. 2007. The first case of breeding of a Golden Eagle Aquila chrysaetos tracked from birth by satellite telemetry. Acta Ornithol. 42: 205-209.

\section{STRESZCZENIE}

\section{[Dyspersja natalna orzełka południowego]}

Aby określić odległości przebywane przez młode orzełki południowe pomiędzy opuszczeniem gniazda a przystapieniem do rozrodu dwa młode ptaki — samca i samicę wyposażono w 2002 w nadajniki telemetrii satelitarnej zasilane baterią sloneczną. Oba ptaki pochodziły z gniazd położonych we wschodniej Hiszpanii.

Samica przeleciała na dość znaczną odległość i dość szybko (po ok. 3 miesiącach - Fig. 2a) osiedliła się na terenie zajmowanym następnie przez kolejne 4 lata, gdzie przystąpiła do pierwszego lęgu (Tab. 1, Fig. 1). Odległość między miejscem, w którym się wykluła a własnym gniazdem wyniosła w linii prostej $441 \mathrm{~km}$. Natomiast samiec w ciągu czterech lat od oznakowania nie był przywiązany do jednego terenu (Fig. 1, 2b). Autorzy sugeruja, ze w tym okresie prawdopodobnie przebywał na wielu różnych terytoriach lęgowych, sprawdzając możliwości gniazdowania, gdyż podobne strategie są obserwowane np. $\mathrm{u}$ orła iberyjskiego. W ciągu czterech lat obserwacji nie zanotowano próby lęgowej podjętej tego osobnika.

Odległość między miejscem wyklucia a własnym gniazdem stwierdzona dla badanej samicy jest jedną $z$ najwyższych zanotowanych do tej pory. 